\title{
Fluoride: its implications for public health
}

\author{
Vázquez-Alvarado Patricia ${ }^{1}$, Hernández Ceruelos María del Carmen Alejandra ${ }^{2}$, Muñoz-Juárez \\ Sergio $^{3}$, Reynoso-Vázquez Josefina ${ }^{4}$, López Contreras Luilli ${ }^{5}$, Ruvalcaba-Ledezma Jesús Carlos ${ }^{6 *}$. \\ ${ }^{1}$ Department of Public Health, Dentistry area [ICSa-UAEH] Institute of Health Sciences-University of the \\ State of Hidalgo. Pachuca Hidalgo, Mexico. ${ }^{2,3}$ Department of Public Health, Medical Area [ICSa-UAEH] \\ ${ }^{4}$ Department of Public Health, Pharmacy Area [ICSa-UAEH].${ }^{5 *}$ Department of Public Health, Medical Area, \\ Doctorate in Food Sciences and Human Health [ICSa-UAEH] Institute of Health Sciences-University of the \\ State of Hidalgo. Pachuca Hidalgo, Mexico. \\ * Author's contact details: dcspjcarlos@gmail.com \\ Corresponding author. PhD. Jesús Carlos Ruvalcaba Ledezma \\ Address: ICSA. Ex Hacienda La Concepción, n/n; Pachuca-Actopan Highway, Tilcuautla Road. Pachuca \\ Hidalgo, Mexico. Tel (771) 7172000 ext. 4308. C.P. 42160. Movil. 5548817657
}

\section{Review}

\begin{abstract}
The use of fluoride $\left(\mathrm{F}^{-}\right)$for decreasing the prevalence and incidence of tooth decay was the greatest worldwide preventive public health measure of the 20th century. There have been controversial reports about the benefits of the use of $\mathrm{F}^{-}$, because in small amounts it helps prevent dental caries, but in high concentrations it can be potentially toxic and harmful to dental and systemic health. Since the mid-20th century, $\mathrm{F}^{-}$has been studied by toxicologists, looking at its deleterious effects in human populations. During the last decade, the interest on the undesirable effects has resurfaced because of the knowledge that it interacts with the cellular system, even in low doses, with a very small safety margin. Acute ingestion of toxic amounts of fluoride can cause corrosive gastric mucosa injury. Also respiratory effects such as bleeding, pulmonary edema, tracheostomy and shortness of breath, have been observed in individuals who inhale hydrogen fluoride. Some researchers had shown that $\mathrm{F}^{-}$is an oxidizing agent and a well-known reversible enzymatic inhibitor that interferes with the enzyme activity of at least 80 proteins, can altered the intracellular redox equilibrium, lipid peroxidation, as well as, alteration in the gene expression and apoptosis induction. The primary purpose of this review is to examine findings of the action of inorganic $\mathrm{F}^{-}$, and an overview of hard and soft tissue disturbances, known as fluorosis. The goal of this review is to enhance understanding of the mechanisms by which $\mathrm{F}^{-}$affects cells with an emphasis on human tissue-specific events.
\end{abstract}

Keywords: Fluoride, fluorosis, fluoride systemic damage, human health.

\section{Introduction}

Fluorine is the 13th more abundant element on the earth's crust. Human beings are exposed to it naturally in the water sources, with levels ranging from 0.1 to more than 25 $\mathrm{mg} / \mathrm{L}$ in fresh water, and from 1.2 to $1.5 \mathrm{mg} / \mathrm{L}$ in sea water (WHO, 2002). Fluorine is not found as a free element, nevertheless, it can be found in rocks and the ground in a huge variety of minerals such as calcium fluoride, $\left(\mathrm{CaF}_{2}\right)$, cryolite $\left(\mathrm{Na}_{3} \mathrm{AlF}_{6}\right)$, apatite $[\mathrm{Ca} 5$ $\left.\left(\mathrm{PO}_{4}\right)_{3} \mathrm{~F}\right]$ and topaz $\left[\mathrm{Al}_{2} \mathrm{SiO}_{4}(\mathrm{FOH})_{2}\right]$. During the formation of some minerals in the presence of fluoride ions, the hydroxyl ion can be substituted in some of them such as muscovite $\left(\mathrm{K}_{2} \mathrm{Al}_{4}\right)\left(\mathrm{Si}_{6} \mathrm{Al}_{2} \mathrm{O}_{20}\right)(\mathrm{OH}, \mathrm{F})_{4}$, that is a kind of mica, and in amphiboles like amosite $(\mathrm{FeMg})_{7}\left(\mathrm{Si}_{4} \mathrm{O}_{11}\right)_{2}(\mathrm{OH})_{4}$, and also in horns of animals $\left.(\mathrm{Ca}, \mathrm{Na})_{2-3} \mathrm{Mg}, \mathrm{Fe}, \mathrm{Al}\right)_{5-}$ $\left.(\mathrm{Si}, \mathrm{Al})_{8} \mathrm{O}_{22} \mathrm{OH}\right)_{2}$. Fluoride can also be found in andosols of volcanoes and as a subproduct 
of phosphate fertilizer production (Delmelle et al., 2003; Msonda et al., 2007; Mirlean and Rosenberg, 2007). $\mathrm{CaF}_{2}$ is found in limestone and sand and it is present in hydrothermal deposits in contact with carbonated rocks. $\mathrm{CaF}_{2}\left(\mathrm{PO}_{4}\right)_{6}$ is part of dolomites and limestone (Hernández, 1997).

Natural products of $\mathrm{F}^{-}$vary in function by the geology of the region, particularly considering the water source by height above sea level, and by geothermal activity (Sánchez et al., 2004; Hurtado and Gardea, 2005). $\mathrm{F}^{-}$in contact with the environment cannot be destroyed, only transformed. Its presence in water depends on $\mathrm{pH}$, water hardness and the presence of materials like clay that have the capacity to interchange ions, transported through the hydrologic cycle. (ATSDR, 2003).

Fluorides are liberated into the environment in a natural way through the weathering and dissolution of minerals, through volcanic emissions, and through sea aerosols. Anthropogenic activities, such as charcoal combustion, the production of iron, aluminum, copper and nickel and the manufacture of glass, bricks and ceramics, also contribute to the release of F- to the air. Flouride is also used in the glue industry. Hexafluorosilicic acid $\left(\mathrm{H}_{2} \mathrm{SiF}_{6}\right)$ and disodium hexafluorosilicate $\left(\mathrm{Na}_{2} \mathrm{SiF}_{6}\right)$ are used in the fluorination of tap water (Hernández, 1997). Human detritus can increase $\mathrm{F}^{-}$concentration in the environment (WHO, 2002).

Most people are generally exposed to low levels of inorganic $\mathrm{F}^{-}$through consumption of drinking water, food and a variety of dental care products $\left(0.03-0.07 \mathrm{mg} \mathrm{kg}^{-1} \mathrm{~d}^{-1}\right)(\mathrm{NRC}$, 2006; Rodrigues et al., 2009). $\mathrm{F}^{-}$is an important naturally contaminant, is found in deep waters at elevated concentrations in numerous parts of the world. In this areas chronic $\mathrm{F}^{-}$ exposure at higher levels $\left(>0.15 \mathrm{mg} \mathrm{kg}^{-1} \mathrm{~d}^{-1}\right)$, mainly through drinking water, can be a significant cause of disease (NRC, 2006).

There is a global endemic problem of underground water that is used for public consumption being contaminated with F- (Amini et al., 2008). Hydrofluorosis has been reported in India (Misra and Mishra, 2006; Choubisa, 2001), China (Ando et al., 2001), Pakistan (Farooqi et al., 2007), Tanzania (Kaseva, 2006), Brazil (Casagranda et al., 2007), Kenya (Gaciri and Davies, 1993), Malawi (Msonda et al., 2007), Taiwan (Lung et al., 2008) and other countries like México (Secretaría de Salud, 2003).

\section{Dynamic of fluoride -in vivo}

In humans and animals, $\mathrm{F}^{-}$absorption occurs mainly in the stomach and the intestine. This process depends of the solubility of the ingested fluorinated compound. In the presence of aluminum, phosphate, magnesium and calcium, the absorption can decrease. The fluoride is quickly distributed through systemic circulation, both intracellularly and extracellularly. In humans and laboratory animals, $99 \%$ of $\mathrm{F}^{-}$is retained in bones and teeth (WHO, 2002). It is able to cross the placental barrier to the fetus, where the levels are lower than those observed in the mother (Caldera et al., 2004). In children, nearly 80 to $90 \%$ of $\mathrm{F}^{-}$is retained, compared to approximately $60 \%$ in adults. The highest concentrations are in calcified tissues bone, dentine and enamel. $\mathrm{F}^{-}$is eliminated from the body in urine, sweat, tears and feces (WHO, 2002). 


\section{Dose-response assessment}

An acute toxic dose of $5 \mathrm{mg} / \mathrm{kg}$ can provoke a variety of effects such as nausea, vomit, abdominal pain, diarrhea, fatigue, somnolence, convulsions, cardiac arrhythmia, coma, respiratory arrest and death. For a human, it has been estimated that a lethal dose for $\mathrm{NaF}$ is between 5 and $10 \mathrm{~g}(32-64 \mathrm{mg} / \mathrm{Kg})$ (ATSDR, 2003). Toxicity of $\mathrm{F}^{-}$depends on the compound ingested. One of the more soluble salts of inorganic $\mathrm{F}^{-}$is $\mathrm{NaF}$, which is more toxic than the less soluble $\mathrm{F}^{-}$salts, such as $\mathrm{CaF}_{2}$ (WHO, 2002).

Fluoride supplements are a risk factor for fluorosis in young children when used inappropriately and not conforming to appropriate dosing schedules. The non-observed adverse effect limit (NOAEL) is based on long-term studies, preferably of ingested drinking water, for $\mathrm{F}^{-}$is $0.05 \mathrm{mg} / \mathrm{kg} /$ body weight in the case of enamel fluorosis. This level, for children under 8 years, will not produce mild fluorosis in permanent teeth. The lowest observed adverse effect limit (LOAEL) causes a detectable adverse health effect. In the context of enamel fluorosis, the LOAEL is $0.1 \mathrm{mg} \mathrm{F}-/ \mathrm{kg}$ body weight. (Browne, 2005).

\section{Fluoride Toxicity in human exposure Teeth}

$\mathrm{F}^{-}$has been shown to have the following effects in dental enamel: an increase in the size of apatite crystals, an improvement in the crystallinity of apatite and an increase in the driving force towards apatite nucleation and growth (Legeros 1991). Scanning and electron micrographic studies of fluorotic enamel have revealed alterations in morphology and crystal defects. (Yanagisawa et.al., 1989) These collective studies suggest that excessive concentrations of $\mathrm{F}^{-}$in developing enamel partially inhibit proteinases that split larger molecular weight amelogenins. Inhibition at the critical stage of enamel formation could have major effects in structural appearance of fully formed enamel. It is important to assess the calcification and eruption dates of primary and permanent teeth in order to identify when developing teeth are at the most risk of enamel fluorosis (Browne, 2005).

Inhibition at the critical stage of enamel formation could have major effects in structural appearance of fully formed enamel. It is important to assess the calcification and eruption dates of primary and permanent teeth in order to identify when developing teeth are at the most risk of enamel fluorosis (Browne, 2005). In a previous study in students from 12 to 15 years old, in the comunity of Ex-Hacienda Tula, México, well water had a mean of fluoride about $1.41 \mathrm{mg} / \mathrm{L}(\mathrm{CI} 95 \%, 1.19,1.64)$ with a dental fluorosis prevalence of $85 \%$ (VazquezAlvarado et al., 2010).

\section{Bone}

Occurrence of $\mathrm{F}^{-}$bone injury is a complex process that involves both exogenous and endogenous factors. Except for $\mathrm{F}^{-}$burden, $\mathrm{F}^{-}$bone injury is also associated with the genetic background (Cooper et al. 2006). By stimulating osteoblasts, $\mathrm{F}^{-}$promotes bone formation in both cortical and trabecular bone, but its effect on trabecular bone is greater, occurs earlier, and leads to a more pronounced increase in spine density on x-ray films (Baylink et al., 1983). Increased risk was due to the excessive $\mathrm{F}^{-}$burden, which could lead to the accumulation of fluorapatite in bone. Fluorapatite is difficult to absorb, can destroy the dynamic balance of bone resorption and formation, and finally leads to bone metabolic disorders depending on the genotype effects where the polymorphic forms TC, TT and CC 
genotypes for the calcitonin receptor (CTR) gene are able to develop more bone injury (Jun et al., 2011).

Flourosis results in an osteocondensation by altering bone mass through effects on skeletal mineralization, impaired bone resorption and ion induced decreased bone strength (Assefa et al., 2004). These are all contradictory effects leading to a combination of osteosclerosis, stress fractures, ligamentous calcification, ossification and a radiculomyelopathy owing to mechanical compressive effects (Tamer et al., 2007; Reddy, 2009). A high concentration of $\mathrm{F}^{-}$in Pakistan is related to vertebral sclerosis, a combination of premature degeneration with anterior disc herniation and an unusual high frequency of vertebral hemangioma. These formed the spectrum of magnetic resonances image findings in subjects with spinal flourosis having backache but no neurological findings. (Ahmed et al., 2013; Sang et al., 2010).

The minimum risk level for fluoride intake is $0.05 \mathrm{mg} / \mathrm{kg}$ / day for chronic oral exposure (Choubisa, 2001). This value has been considered the toxic threshold that can cause dental fluorosis, skeletal fluorosis, bone deformation and mainly hip fractures (Alarcón et al., 2001).

\section{Adverse effects on soft organs}

In liver, kidney, parotid glands and brain, damage have been observed (Shan et al., 2004; Shantakumari 2004; Wang et al., 2004). There is also a higher risk of brain damage and IQ reduction in children (Wang et al., 2007) as well as soft tissues such as reproductive organs, and the endothelium (NRC, 2006). Exposure to $\mathrm{F}^{-}$increases the production of superoxide as a consequence of hydrogen peroxide metabolism inducing eroxinitrate, hydroxyl radicals, and increasing oxidative stress (Barbier et al., 2010; Garcia-Montalvo et al., 2009; Chinoy, 2003) and inducing lypoperoxidation of membranes, apoptosis and DNA damage (Wang et al., 2007). The clinical application of $\mathrm{NaF}$ induced genotoxicity on the oral epithelium in acute exposition according to Vázquez-Alvarado et al., (2012). Tiwari and Rao (2010) considered $\mathrm{F}^{-}$as a mutagenic agent that even in low concentrations can increase the induction of chromosomal aberrations.

\section{Reproductive system}

Reproductive function of female rats was markedly damaged when they were exposed to $\mathrm{NaF}(100,150$ and $200 \mathrm{mg} / \mathrm{L})$. The endometrial cells became larger, and the endometrial glands became hypertrophic. The total number of each type of follicle was changed in $\mathrm{NaF}$ groups: the number of small follicles increased and the large follicle number decreased. This indicates that sufficiently high fluoride intake through drinking water may reduce female reproductive function by affecting steroidogenesis and steroid hormone receptor expression, underlying poor reproduction in females that have been exposed to sodium fluoride (Zhou et al., 2013) .

\section{DNA alterations}

The high concentration of $\mathrm{F}^{-}$also affected DNA of epithelial cells, making them susceptible to mutations, transformation and the development of neoplasia. (Guachalla and Ascarrunz, 2003). In a study the increase in DNA damage of epithelial cells when they were in contact with $\mathrm{NaF}(2 \%)$ made evident the high genotoxic potential of $\mathrm{F}^{-}$, since most of the cells of 
this group were classified with the maximum degree of damage (45\%). Considering that the samples were taken from the same students used for negative control, the topical appliance of fluoride gel on teeth is able to induce a very significant DNA damage on the oral epithelial cells in an acute exposure. In a community with water concentration for human consumption of $1.67 \mathrm{mg} / \mathrm{L}$, severe genotoxic damage was observed in oral epithelial cells with the comet assay, similar to that observed after the clinical appliance for $\mathrm{NaF}$ (Vázquez-Alvarado et al., 2012).

\section{Oxidative stress}

Chronic fluoride exposure can induce oxidative stress (Bouaziz et al., 2007), while oxidative stress is closely related to inflammation and endothelial cell activation. The excess fluoride promotes atherosclerosis by inducing oxidative stress and endothelial activation. Experimental studies in animals have demonstrated that the atherogenic effect and inflammatory responses are due to fluoride, and not lipid metabolic disorder, which plays a crucial role in the cardiovascular toxicity of fluoride (Flora et al., 2011; Gamkrelidze, et al., 2008). A positive closed relationship between fluoride exposure and the prevalence of carotid artery atherosclerosis was found using cross-sectional study. It is also noted that elevated inter cellular adhesion molecule 1 (ICAM-1) and decreased glutatine peroxidase (GPx) were associated with carotid atherosclerosis in fluoride endemic areas (Liu et al., 2014).

Decreased expression of insulin mRNA in pancreatic TC-6 cells could be associated with oxidative stress induced by $\mathrm{F}^{-}$exposure. Sakai et al., (2003) reported that hydrogen peroxide in murine pancreatic cells (MIN6) induced mitochondrial ROS, which suppressed first-phase Glucose-stimulated insulin secretion (GSIS), at least, in part through the suppression of Glyceraldhyde-3-phosphatedehydrogenase (GAPDH) activity. Some authors propose that mitochondrial overwork may be a potential mechanism through which firstphase GSIS becomes impaired in the early stages of diabetes mellitus. Furthermore, Kaneto et al., (2005) reported that when oxidative stress was induced in cells in vitro, insulin gene promoter activity and mRNA levels were suppressed.

They were accompanied by a reduced activity of pancreatic and duodenal homeobox factor1 (PDX-1), which is an important transcription factor for the insulin gene. Moreover, diabetic individuals may have higher $\mathrm{F}^{-}$intake and retention than healthy individuals due to increased water intake and decreased renal clearance. Also, there is increased retention of $\mathrm{F}^{-}$in the body for patients with kidney damage, or those with compromised renal clearance, such as the elderly, and those whose diets are deficient of $\mathrm{Ca}^{2+}$. Therefore, in these conditions, the severity of the diabetes could increase as the $\mathrm{F}^{-}$exposure increases (GarcíaMontalvo et al., 2009).

\section{Brain damage}

Epidemiological evidence supports that fluoride may impair children's learning and memory ability. Children's intelligence quotient (IQ) scores are significantly lower in highlevel fluoride areas of Shanxi Province compared to those of children in non-endemic areas (Wang et al., 2007). Calderon et al., (2000) found that 6-8-year-old children showed lower reaction rates and reduced abstract thinking ability in the city of San Luis Potosi (Mexico), which is probably due to long-term excessive intake of fluoride through drinking water. 
Pereira et al., (2011) found that NaF-induced memory impairment was associated with NA and 5- HT increases in discrete rat brain regions. In addition, fluoride may affect the activity of some enzymes in the brain. Bharti et al. (2012) confirmed that $\mathrm{F}^{-}$significantly reduces acetylcholine esterase (AchE) content in rat brain. Degroot et al., (2002) found that AchE can inhibit the formation of physostigmine in either the dorsal or the ventral hippocampus, resulting in increased exploratory behavior in the open arm elevated-plus maze, which was in accordance with the findings of Liu et al., (2014). The learning and memory deficits are the result of interaction of fluoride with the activity of the enzyme acetylcholine esterase. Exposure to fluoride also results in a decrease of the nicotinic acetylcholine receptors (Shan et al., 2004). Fluoride exposed rats showed inhibition of spontaneous motor activity, due to alterations in the function of neurotransmitters, their structure and cholinergic mechanisms (Raghu et al., 2013).

\section{Hypertension and excess of $\mathrm{F}^{-}$}

Essential hypertension is the most common type of hypertension (HTN) in $90 \%$ of patients. Although the root causes of HTN are still being explored, endocrine system components such as the renin-angiotensin system, mineralocorticoids, catecholamines, endothelins (ET), and nitric oxide (Carey, 2011) have been demonstrated to play an important role in essential HTN.

In recent years, the role of ET in HTN has received more attention. As the principal member of the ET family, Endothelin-1 (ET-1) was originally isolated and characterized from the culture media of aortic endothelial cells (Yanagisawa et al., 1988). ET-1 carries out a variety of physiological and pathophysiological functions in vascular biology, and its main action is to increase blood pressure (BP) and vascular tone (Agapitov and Haynes, 2002; Kawanabe and Nauli, 2011). Moreover, ET-1 was suggested to play a crucial role in several cardiovascular diseases, including congestive heart failure (CHF), HTN, atherosclerosis (AS), renal disease and many others (Masaki, 2004; Khimji and Rockey, 2010).

There is a significant relationship between an excess of $\mathrm{F}^{-}$exposure from drinking water and essential HTN in adults living in fluoride endemic areas; although, the underlying mechanisms were somewhat unclears, the ET-1 might be related with this phenomenon (Sun et al., 2013). Vascular oxidative stress could contribute to vascular stiffness (Delles et al., 2008; Noma et al., 2007). With an increase of fluoride concentrations in drinking water, vascular compliance decreased and stiffness increased (Varol et al., 2010; Varol and Varol, 2012).

\section{Cholesterol and fluoride}

The liver is the most effective organ of the body in synthesizing cholesterol. There are significantly adverse changes in the lipid and lipoprotein profiles, total cholesterol, highdensity lipoprotein (HDL), low-density lipoprotein (LDL) and triglycerides in postmenopausal women (Oral and Ozbasar 2003) and fluorotic patients (Shashi and Kumar 2008; Juganmohan et al., 2010). Fluorides reduce lipoprotein lipase (LPL) activity and cause a diminished peripheral removal of lipoproteins in plasma (Kokotos et al., 2010). Theoretically, the reduction in LPL activity could result from the direct inhibition of the enzyme by fluorides, or from the decreased levels of plasma apoprotein CII, known as an 
activator of LPL. The decline in the cholesterol content may be due to inhibition of lipid synthesis by fluoride as well as increased utilization of stored lipids as a source of energy to conduct regular metabolic functions. Fluoride is a well-known inhibitor of lipases, phosphatases, esterases, and acetyl Co-A synthetase. It interferes with fatty acid oxidation which results in decreased synthesis of cholesterol from Acetyl Co-A (Bennis et al., 1993). Fluoride reduces the absorption of cholesterol and bile salt from plasma and intestine, which could result in an increased conversion of bile acids in the liver. Bile acids are known to inhibit cholesterol synthesis in the intestine. This is indicative of hepato-biliary disturbances in fluoride intoxication (Cao et al., 2014).

A study showed hypocholestrolemia and hypolipidemia, and hypertriglyceridemia, and revealed a significantly increased TC/HDL, and LDL/HDL ratio in fluorotic patients. High fluoride levels in drinking water may prevent atherosclerosis. Hypocholesterolemia was observed in patients affected with fluorosis due to high fluoride intake through drinking water. Fluoride may cause disturbances in lipid metabolism (Bhardwaj and Shashi 2013). The decline in the cholesterol content may be due to inhibition of lipid synthesis by fluoride as well as increased utilization of stored lipids as a source of energy to conduct regular metabolic functions. Flavonoids reduce the levels of cholesterol in plasma and thus slow down the process of atherosclerosis in blood vessels. Biochemical work on lipid metabolism and endemic fluorosis is limited and results are conflicting. Earlier workers demonstrated decreased levels of cholesterol in the patients with skeletal fluorosis (Chinoy et al., 1992).

\section{Renal failure}

During tooth formation, renal insufficiency is also associated with defective tooth structure and in particular, enamels hypoplasia (Farge et al., 2006). In patients with renal insufficiency, the decreased ability to excrete $\mathrm{F}^{-}$leads to increased retention of this anion. Donacian et al., (2008) tested that uremia aggravates the $\mathrm{F}^{-}$, inducing changes in developing teeth of rats incisors. This tooth model continuously erupts and contains all stages of dentine and enamel formation in a single tooth. There are series of retrospective clinical studies in children or adults with chronic renal failure, end-stage renal disease, or following kidney transplantation that have associated poor renal function with enamel developmental defects in primary (mainly canines) and permanent dentition (Lucas and Roberts 2005; Al Nowaiser et al., 2003).

The transitional-stage ameloblast appears to be particularly sensitive to both the effects of uremia and $\mathrm{F}^{-}$(Lyaruu et al., 2006). The effects of uremia are primarily in the dentine but also occur in enamel, resulting in hyperplasia and pitting of the enamel surface. The crown portion of human central incisors (the most aesthetically visible teeth) forms up to approximately five years of age, with the second permanent molars forming by about eight year of age. Therefore, children who present with renal insufficiency before the age of eight years are at risk for tooth defects. These effects will be more severe with an increased ingestion of $\mathrm{F}^{-}$by young children with renal failure. $\mathrm{F}^{-}$supplements or swallowing $\mathrm{F}^{-}$ containing toothpaste is contraindicated as suggested previously (Lucas and Roberts 2005). Further studies to determine the specific stage of uremia and $\mathrm{F}^{-}$on tooth formation may result in a better understanding of the overall effects of uremia on mineralized tissues such as dentine, enamel and bone (Donacian et al., 2008) 


\begin{abstract}
Apoptosis
Apoptosis plays an important role in $\mathrm{F}^{-}$toxicity in several cell types, including pancreatic cells possibly because of the involvement of oxidative stress, as reported for HL-60 cells exposed to $2 \mathrm{mM} \mathrm{NaF}$ (Anuradha et al., 2001) or primary cultured hippocampal neurons exposed to $0.476,0.952$ and $1.904 \mathrm{mM} \mathrm{NaF}$ (Zhang et al., 2007). The effects of $\mathrm{F}^{-}$on glucose metabolism have been examined in both in vivo and in vitro studies. Trivedi et al., (1993) reported impaired glucose tolerance in 10 of 25 residents of an area with endemic fluorosis. An increase of $17 \%$ in serum glucose was observed in rabbits administered with $\mathrm{F}^{-}$in drinking water at $100 \mathrm{mg} / \mathrm{L}$ for 6 months (Turner et al., 1997). Additionally, Rigalli et al., (1995) reported a decreased in insulin levels, an increased in plasma glucose and a disturbance of the glucose tolerance test in rats after an oral dose of a solution $40 \mathrm{M} \mathrm{NaF}$ per $100 \mathrm{~g}$ body weight. In vitro studies have been controversial, for example, Komatsu et al., (1995) found that, in rat insulinoma (RINm5F) cells exposed to 5-15 mM NaF increased insulin release for up to 60 minutes in a dose-dependent manner. Studies done in Langerhans islets isolated from rats showed a relationship between $\mathrm{F}^{-}$exposure and decreased insulin secretion. However, Menoyo et al. (2005) found an inhibitory effect on insulin secretion at micromolar concentrations (5-20 M).
\end{abstract}

\title{
Conclusions
}

Because of the universal presence of fluorides in the earths's crust, it is found in rivers, lakes, oceans and underground water. Also in rocks, sediments, andosols volcanoes, in air biota, dead organic matter and anthropogenic sources.

$\mathrm{F}^{-}$is absorbed by living things; it is very toxic when ingested in amounts over 0.05 $\mathrm{mg} / \mathrm{kg} /$ day for a chronic oral exposure, is considered a potentially toxic trace element with a very small safety margin.

This work focus on showing the effects of inorganic $\mathrm{F}^{-}$on the cellular function of several tissue systems. The studies described above demonstrated that chronic toxic effects of $\mathrm{F}^{-}$ can interact with a wide range of cellular processes and systems, as well as, hard tissues included dental fluorosis, skeletal fluorosis, bone deformation and hips fractures. Fluoride toxicity is also related with damage to soft tissues like kidney, liver, reproductive organs and brain.

Nevertheless, the complexity of fluoride's effects on these processes should be appreciated because the effects induced by $\mathrm{F}^{-}$are closely related to dose and concentrations that can be managed with appropriate exposure limits principally for drinking water, to avoid risk for public health.

Acknowledgements. The authors of the present research article would like to acknowledge and truly thank the collaboration of Yesenia Elizabeth Ruvalcaba Cobián for her contributions on the revision of the article.

The authors declare that there is no conflict of interests for the publication of this research paper. 


\section{REFERENCES}

-Alarcón-Herrera MT, Martín-Domínguez IR, Trejo-Vázquez et al. (2001). Well water fluoride, dental fluorosis, and bone fractures in the Guadiana Valley of Mexico. Fluoride; 34:139-149.

-Agapitov AV and Haynes WG. (2002). Role of endothelin in cardiovascular disease. J Renin Angiotensin Aldosterone Syst, 3: 1-15.

-Amini M, Abbaspour KC, Berg M et al. (2008). Statistical modeling of global geogenic arsenic contamination groundwater. Environ Science \& Technol; 42: 3669-3675.

-Ando M, Tadano M, Yamamoto S et al. (2001). Health effects of fluoride pollution caused by coal burning. The Sci of the Total Environ, 271: 107-116.

-Anuradha CD, Kanno S, Hirano S. (2001). Oxidative damage to mitochondria is a preliminary step to caspase-3 activation in fluoride-induced apoptosis in HL-60 cell. Free Radical Biol Med, 31: 367-373.

-Assefa G, Sheifera G, Melaku Z et al. (2004). Clinical and radiological prevalence of skeletal fluorosis among retired employees of Wonji-Shoa sugar estate in Ethiopia. East Afr Med J, 81: 638-640.

-ATSDR (Agency for Toxic Substances and Disease Registry). (2003). Toxicological Profile for Fluorine, Hydrogen Fluoride and Fluorides, Atlanta, GA, US. Department of Health and Human Services, Public Health Services.

-Al Nowaiser A, Roberts GJ, Trompeter RS et al. (2003). Oral health in children with chronic renal failure. Pediatr Nephrol, 18: 39-45.

-Ahmed I, Sohail S, Hussain M et al. (2013). MRI features of spinal Fluorosis: Results of an endemic community screening. Pak J Med Sci, 29: 177-180.

-Barbier O, Arreola-Mendoza L, Del Razo LM. (2010). Molecular mechanisms of fluoride toxicity. ChemicoBiologic Interact, 188: 319-333.

-Bawden JW, Crenshaw MA, Wright JT et al. (1995). Considerations of possible biologic mechanisms of fluorosis. J Dent Res, 74: 1349-52.

-Baylink DJ, Duane PB, Farley SM et al. (1983). Monofluorophosphate physiology: the effects of fluoride in bone. Caries Res, 17: 56-76.

-Bennis A, Kessabi M, Hamliri A. (1993). Plasma biochemistry of adult goats with chronic fluoride poisoning in Morocco. Fluoride, 26: 241-6.

-Bhardwaj A and Shashi, D. (2013). Dose effect relationship between high fluoride Intake and biomarkers of lipid metabolism in endemic fluorosis. Biomedicine and Preventive Nutrition, 3: 121-127.

-Bouaziz H, Boudawara F, Soleihavoup JP. (2007). Oxidative stress induced by fluoride in adult mice and their suckling pups. Exp Toxicol Pathol, 58: 339-349.

-Browne D, Whelton H, O'Mullane. (2005). Fluoride metabolism and fluorosis. J Dentistry, 33: 177-186.

-Bharti VK, Srivastava R, Anand AK et al. (2012). Buffalo (Bubalus bubalis) epiphyseal proteins give protection from arsenic and fluoride-induced adverse changes in acetylcholinesterase activity in rats. $J$ Biochem Mol Toxicol, 26: 10-5. 
-Calderon J, Machado B, Navarro M et al. (2000). Influence of fluoride exposure on reaction time and visuospatial orcanization in children. Epidemiology, 11: 5153.

-Cao J, Chen J, Wang J et al. (2014). Effects of sodium fluoride on MAPKs signaling pathway in the gills of a freshwater teleost, Cyprinus carpio. Aquatic Toxicol, 152: 164-172.

-Carey RM. (2011). Overview of endocrine systems in primary hypertension. Endocrinol Metab Clin North Am, 40: 265-77.

-Casagranda MP, Knöler K, Roisenberg A. (2007). Anomalous fluoride concentration in groundwater is it natural or pollution? A stable isotope approach, Isotopes. Environ and Health Studies, 43: 165-175.

-Cooper LF, Zhou Y, Takebe J et al. (2006). Fluoride modification effects on osteoblast behavior and bone formation at TiO2 grit-blasted c.p. titanium endosseous implants. Biomaterials, 27: 926-936.

-Chinoy NJ, Narayana MV, Sequeria E et al. (1992). Studies on effects of fluoride in 36 villages of Mehsana district, North Gujarat. Fluoride, 25: 63-71.

- Choubisa SL. (2001). Endemic fluorosis in southern Rajasthan, India. Fluoride, 34: 61-70.

-Chinoy NJ. (2003). Fluoride stress on antioxidant defense systems. Fluoride, 36: 138-141.

-Delmelle P, Delfosse T, Delvaux B. (2003). Sulfate, chloride and fluorosis retention in Andosols exposed to volcanic acid emissions. Environ Pollut, 126: 445-457.

-Delles C, Zimmerli Lu, McGrane DJ et al. (2008). Vascular stiffness is related to superoxide generation in the vessel wall. J Hypertens, 26: 946-55.

-Degroot A and Treit D. (2002). Dorsal and ventral hippocampal cholinergic systems modulate anxiety in the plus-maze and shock-probe tests. Brain Res; 949: 60-70.

-Donacian M. Lyaruu A, Bronckers LJJ. (2008). The effect of fluoride on enamel and dentin formation in the uremic rat incisor. Pediatr Nephrol, 23: 1973-1979.

-Farge P, Ranchin B, Cochat P. (2006). Four-year follow-up of oral health surveillance in renal transplant children. Pediatr Nephrol, 21: 851-855.

-Farooqi A, Masuda H, Firdous N. (2007). Toxic fluoride and arsenic contaminated groundwater in the Lahore and Kasur districts, Punjab, Pakistán and possible contaminant sources. Environ Pollut, 145: 839-849.

-Flora SJ, Pachauri V, Mittal M, Kumar D. (2011). Interactive effect of arsenic and fluoride on cardiorespiratory disorders in male rats: posible role of reactive oxygen species. Biometals, 24: 615-628.

-Gamkrelidze M, Mamamtavrishvili N, Bejitashvili N et al. (2008). Role of oxidative stress in pathogenesis of atherosclerosis. Georgian Med News, 54-57.

-Guachalla L, Ascarrunz M. (2003). Genetic Toxicology: a science in constant development. Biofarbo, XI: 75-82.

-Gaciri SJ and Davies TC. (1993). The occurrence and geochemistry of fluoride in some natural waters of Kenya. J Hidrol,143: 395-412.

-García-Montalvo, Reyes-Pérez H, Del Razo LM. (2009). Fluoride exposure impairs glucose tolerance via decreased insulin expression and oxidative stress. Toxicol, 263: 75-83. 
-Hernández A. El flúor y el Abastecimiento del Agua. (1997). Tecnología Internacional del agua, Madrid, España, pp. 26-239.

-Hurtado R and Gardea-Torresdey J. (2005). Estimación de la exposición a fluoruros en los Altos de Jalisco, México, Salud Pública Mex, 47: 58-63.

-Juganmohan P, Rao SVLN, Rao KRSS. (2010). Lipid abnormalities in fluoride induced renal failure patients of Nellore District, Andhra Pradesh, India. Afr J Basic Appl Sci, 2: 94-8.

-Jun T, Liu K, Song Y et al. (2011). Interactive effect of fluoride burden with calcitonin receptor gene polymorphisms on the risk of F bone injury. Int Arch Occup Environ Health, 84: 533-538.

-Kaseva ME. (2006). Contribution of trona (magadi) into excessive fluorosis-a case study in Maji ya Chaid ward, northern Tanzania. Sci of the Total Environ, 366: 92-100.

-Kaneto H, Kawamori D, Matsuoka T et al. (2005). Oxidative stress and pancreatic $\beta$-Cel dysfunction. Am $J$ Ther, 12: 529-533.

-Kawanabe Y and Nauli SM. (2011). Endothelin. Cell Mol Life Sci, 68: 195-203.

-Komatsu M, McDermott AM, Sharp GW. (1995). Sodium fluoride stimulates exocytosis at a late site of calcium interaction in stimulus-secretion coupling: studies with the RINm5F beta cell line. Mol Pharmacol, 47: 496-508.

-Kokotos G, Kotsovolou S. Constatinou Kokotou V. (2010). Inhibition of lipoproteins lipase by alkanesulfonyl fluorides. Bioorg Med Chem Lett, 24: 2803-6.

-Khimji AK and Rockey DC. (2010). Endothelin-biology and disease. Cell Signal, 22: 1615-25.

-K, Matsumoto K, Nishikawa T et al. (2003). Mitochondrial reactive oxygen species reduce insulin secretion by pancreatic beta-cells. Biochem Biophys Res Commun, 300: 216-222.

-Lantz O, Jouvin MH, DeVernejoul et al. (1987). Fluoride-induced chronic renal failure. Am J Kidney Dis, 10: 136-139.

-Liu F, Ma J, Zhang H et al. (2014). Fluoride exposure during development affects both cognition and emotion in mice. Physiol \& Behaivor, 124: 1-7.

-LeGeros RZ and Tung MS. (1983). Chemical stability of carbonate and fluoride containing apatites. Caries Res, 17: 419-29.

-LeGeros RZ. (1991). Calcium phosphates in oral biology and medicine. In: Monograph in oral science, vol: 15 Basel-Karger.

-Lucas VS and Roberts GJ. (2005). Oro-dental health in children with chronic renal failure and after renal transplantation: a clinical review. Pediatr Nephrol, 20: 1388-1394.

-Lung S, Cheng H, Fu C. (2008). Potencial exposure and risk of fluoride intakes from tea drinks produced in Taiwan. Journal of Exposure Sci and Environ Epidemiol, 18: 158-166.

-Lyaruu DM, Bervoets TJ, Bronckers AL. (2006). Short exposure to high levels of fluoride induces stagedependent structural changes in ameloblasts and enamel mineralization. Eur J Oral Sci, 114: 111-115. 
-Masaki T. (2004). Historical review: endothelin. Trends Pharmacol Sci, 25: 219-24.

-Menoyo I, Rigalli A, Puche RC. (2005). Effect of fluoride on the secretion of insulin in the rat. Arzneimittelforschung, 55: 455-460.

-Mirlean N and Rosenberg A. (2007). Fluoride distribution in the environment along the gradient of a phosphate-fertilizer production emission (southern Brazil). Environ Geochem Health, 29:179-187.

Msonda KWM, Masamba WRL, Fabiano E. (2007). A study fluoride groundwater occurrence in Nathenje. Physics \& Chemistry of the Earth,32: 1178-1184.

-Misra AK and Mishra A. (2006). Study of quaternary aquifers in Ganga Plain, India: Focus on groundwater salinity, fluoride and fluorosis. J of Hazardous Mat, 144: 438-448

-Msonda KWM, Masamba WRL, Fabiano E. (2007). A study fluoride groundwater occurrence in Nathenje, Physics \& Chemistry of the Earth; 32: 1178-1184.

-NRC (National Research Council). (2006). Fluoride in drinking-water, a scientific review of EPA's standards. Washington DC.

-Noma K, Goto C, Nishioka K et al. (2007). Roles of rho-associated kinase and oxidative stress in the pathogenesis of aortic stiffness. J Am Coll Cardiol, 49: 698-705.

-Oral B and Ozbasar D. (2003). The effect of sodium monofluorophosphate therapy on lipid and lipopotrein metabolism in postmenopausal women. Eur J Obstet Gynecol Reprod Biol, 2: 180-4.

Pereira M, Dombrowski PA, Losso EM et al. (2011). Memory impairment induced by sodium fluoride is associated with changes in brain monoamine levels. Neurotox Res, 19: 55-62.

-Raghu J, Raghuveer VC, Rao MC et al. (2013). The ameliorative effect of ascorbic acid and Ginkgo biloba on learning and memory deficits associated with fluoride exposure. Interdiscip Toxicol, 6: 217-221.

-Reddy DR. (2009). Neurology of endemic skeletal fluorosis. Neurol India, 57: 7-12.

-Rigalli A, Alloati R, Menoyo I et al. (1995). Comparative study of the effect of sodium fluoride and sodium monofluorophosphate on glucose homeostasis in the rat. Arzneimittelforschung; 45: 289-292.

-Rodrigues MH, Leite AL, Arana A et al. (2009). Dietary fluoride intake by children receiving different sources receptor genes. Toxicol, 200: 169-177.

-Shan KR, Qi XL, Long YG et al. (2004). Decreased nicotinic receptors in PC12 cells and rat brains influenced by fluoride toxicity-a mechanism relatin to a damage at the level in post-transcription of the Sakai of systemic fluoride. J Dent Res,88: 142-145.

-Sánchez S, Pontigo AP, Heredia E, et al. (2004). Fluorosis dental en adolescentes de tres comunidades del estado de Querétaro. Revista Mexicana de Pediatría, 71: 5-9.

-Sang ZC, Zhou W, Zhang ZJ et al. (2010). X-ray analysis on 114 patients with moderate endemic skeletal fluorosis by treatment of Guo's Chinese herbal. Zhongguo Gu Shang, 23: 379-382.

-Secretaría de Salud, Subsecretaría de Prevención y Promoción de la Salud, Centro Nacional de Vigilancia Epidemiológica y Control de Enfermedades. (2003). Manual para el uso de fluoruros dentales en la República Mexicana, México. 
-Sun, L., Gao, Y., Liu, H., et al. (2013). An assessment of the relationship between excess fluoride intake from drinking water and essential hypertension in adults residing in fluoride endemic áreas. Sci. of the Total Environment, 443: 864-869.

-Shanthakumari D, Srinivasalu S, Subramanian S. (2004). Effect of fluoride intoxication on lipidperoxidation and antioxidant status in experimental rats. Toxicol, 204: 219-228.

-Shashi A and Kumar M. (2008). Age specific fluoride exposure in drinking water a clinical multiparametric study. Asian J Microbiol Biotech Environ Sci, 3: 145-50.

-Tamer MN, Kale KB, Arsalan C et al. (2007). Osteosclerosis due to endemic fluorosis. Sci Total Environ, 373: 43-48.

-Tiwari H and Rao MV. (2010). Curcumin supplementation protects from genotoxic effects of arsenic and fluoride. Food Chem Toxicol, 48: 1234-1238.

-Turner CH, Garetto LP, Dunipace AJ. (1997). Fluoride treatment increased serum IGH-1, bone turn over and bone mass, but not bone strength in rabbits. Calcif Tissue Int, 61: 77-83.

-Trivedi N, Mithal A, Gupta SK. (1993). Reversible impairment of glucose tolerance in patients with endemic fluorosis. Fluoride Collaborative Study Group. Diabetología, 36: 826-828.

Varol E, Akcay S, Ersoy IH et al. (2010). Aortic elasticity is impaired in patients with endemic fluorosis. Biol Trace Elem Res, 133: 121-7.

-Varol E and Varol S. (2012). Effect of fluoride toxicity on cardiovascular systems: role of oxidative stress. Arch. Toxicol, 86: 1627..

-Vázquez-Alvarado P, Meléndez-Ocampo A, Ortiz-Espinosa R et al. (2012). Genotoxic damage in oral epithelial cells induced by fluoride in drinking-water on students of Tula de Allende. Hidalgo, Mexico. $J$ Toxicol. and Environ. Health Sci, 4: 123-129.

-Vázquez-Alvarado P, Prieto-García F, Coronel-Olivares C et al. (2010). Fluorides and dental fluorosis in students from Tula de Allende, Hidalgo, México. J Toxicol and Environ Health Sci, 2: 24-31.

-Wang AG, Xia T, Chu QL et al. (2004). Effects of fluoride on lipid peroxidation. DNA damage and apotosis in human embryo hepatocytes. Biomedic Environ Scie, 17: 217-222.

-Wang SX, Wang ZH, Cheng XT et al. (2007). Arsenic and fluoride exposure in drinking water: children's IQ and growth in Shanyin County, Shanxi, China. Environ Health Perspectives, 115: 643-647.

-World Health Organization. (2002). Fluorides. Environmental Health Criteria 227. Geneva.

-Yanagisawa T, Takuma S, Fejerskov O. (1989). Ultraestructure and composition of enamel in human dental fluorosis. Advances in Dental Res, 3: 203-10.

-Zhang M, Wang A, He W. (2007). Effects of fluoride on the expression of NCAM, oxidative stress, and apoptosis in primary cultured hippocampal neurons. Toxicol, 236: 208-216.

-Zhou Y, Qiu Y, He J, et al. (2013). The toxicity mechanism of sodium fluoride on fertility in female rats. Food Chemi Toxicol, 62: 566-572. 